\title{
An Assessment of Students ${ }^{\text {ee }}$ Perception towards Environmental Education and Its Practice: The Case of Combolcha, Hote, Adjibar and Masha Secondary Schools of South Wollo Zone, Amhara Regional State, Ethiopia
}

\author{
Ashenafi Yimam \\ School of Geography \& Environmental Studies, Haramaya University, Dire Dawa, Ethiopia
}

\begin{abstract}
The main objective of this study was to assess perceptions of students' towards environmental education and its practice in the selected secondary schools. Four schools were considered through purposive sampling. From the sample schools a total of 385 participants were selected through stratified and random sampling techniques. In this study, criterion-referenced test, likert-type scale and open- ended questionnaires', were developed to collect the relevant data from the students'. Then the collected data were analyzed both qualitatively and quantitatively (using descriptive statistics like; percentage, frequency, mean and standard deviation and parametric statistics like; T-test and One-way ANOVA). Based on result students' environmental knowledge test score showed that, the majority of the students' performed below the standard set (70\%) by their teachers'. However, when their achievement scores were analyzed in terms of gender statistically insignificant mean difference was obtained, $t(383)=0.54, p>0.05$. On the contrary, the mean difference between grade nine and ten students' were found significant, $t(383)=3.07, p<0.05$. And the ANOVA summary did show significant mean difference in the schools as a whole, $F(3,381)=2.92, p<0.05$. Finally, regarding their behavioral practices of students' in their environment was found having low practices. The analysis made based on the independent variables (grade level and gender) students' mean difference score were obtained insignificant, $t(383)=0.51, p>0.05$ and $t(383)=0.26, p>0.05$ respectively. The ANOVA summary showed that, statistically significant mean difference in the schools as a whole, $F(3,383)=15.93, P<0.05$. Thus, based on the above result it can be concluded that, students' did not have the right knowledge about their environment and also students' did not show initiation in solving their local environmental problems practically. Based on these findings, some specific recommendations were made for implementation.
\end{abstract}

Keywords: Environmental Education (EE), Environmental Perception, Environmental Practice Gender, Grade Level, Ethiopia

\section{Introduction}

As early as 1988, World Wide Fund-United Kingdom (WWF-UK) had made a remarkable statement regarding the functionality and usefulness of environmental education when it noted that "environmental education is fundamental to the well-being of the planet and of its inhabitants". Through the exploration and development of insights, awareness, knowledge, skills and attitudes it develops essential competencies that enable people to make reasoned responses to the individual and social use of the environment" (WWF-UK, 1988).

Outdoor Education, Adventure Education, and Environmental Education should be placed in the extracurricular programme of schools. It has been seen, however, that the skill component of environmental education, particularly the higher-order skills and more specifically those associated with participation, is very difficult to inject into the academic work of schools. The time factor, the assessment procedure, the authoritarian nature of teaching and the expectations of children, teachers and parents, all militate against engaging in real environmental issues in the community (Smith, 2002).

The 1980 UNESCO conference which introduced the concept of sustainable development stressed African governments to undertake their own national strategies satisfying one of the objectives of the Stockholm conference recommending mass environmental literacy so that there can be literate and democratic decisions towards protecting environment and associated problems. After five years the importance of EE was first realized in Ethiopia, in 1985 , through a Swedish International Development Agency (SIDA) which funded a pilot project known as the Ethiopian Environmental Education Project focusing mainly on the severely drought affected area i.e. northern part of the country (Beletu and Yousef, 1990).

Since then, the role of EE has gained wider recognition by the Government of Ethiopia. Subsequently, the policy deals with environmental education and awareness to develop and promote the teaching of environmental education on a multidisciplinary basis and to integrate it in to the ongoing curricula of schools and colleges (EPA, 1997).

Now a days the need for educational intervention, under the name ,environmental education, " in developing sensitivity to environmental care, in enabling people to regulate their behavior and act responsibly has received much attention. Many countries have already started such kinds of educational program and gained considerable positive results and still make environmental education a high priority (Schneider, 1991). Environmental education was introduced into school $^{\text {ee }} \mathrm{s}$ curriculum, to provide with accurate information about environmental situation and 


\section{International Journal of Science and Research (IJSR) \\ ISSN (Online): 2319-7064 \\ Index Copernicus Value (2013): 6.14 | Impact Factor (2015): 6.391}

stimulate children 's attitudes and behavior change for better (UN, 1972).

It is an undeniable fact that human beings are having a significance impact on the natural environment. As the global population continues to rise, humans place more and more pressure on a finite number of resources. Human environmental impacts can largely be attributed to consumption patterns. The best way to promote awareness for environmental issues and promote environmentally responsible behaviors is through increase access to environmental education (Sabrina, 2005).

Owing to this, environmental education being offered in Ethiopia secondary school level is relatively new educational innovation when it is compared with other educational practices. As to the study area, though the Zone was rich in terms of its environmental resources in the past, currently the ecosystem is being changed at an alarming speed and the natural environment is being degraded due to various human actions such as; deforestation, over-grazing, soil erosion etc. In halting such situations, a lot is expected from schools in shaping the future generations in addition to other activities that various stake holders like; communities, governmental and non-governmental organizations could play.

Nevertheless, the issue has not yet got researchers attention in spite of the importance of the topic. Therefore, it is from this point of view that the researcher find interests to assess students ${ }^{\text {ee }}$ perception towards environmental education and its practice in attempt to approach the actual teachinglearning processes intentionally, in Hote, Combolcha, Adjibar and Masha secondary, with particular reference to grade Nine and Ten Geography and Biology students.

The following objectives guided this study:

1) To asses students ${ }^{\text {ee }}$ environmental knowledge and understanding and behavioral practices in their environment.

2) To identify whether there is a significant difference between students ${ }^{\text {ee }}$ environmental knowledge and behavioral practice in terms of their grade level, gender, and place of residence and among the schools.

\section{Research Methodology}

A descriptive survey method was applied to accomplish the research work at a given time and cost.

The study was conducted in Amhara Regional Governmental State, South Wollo Zone, it lies on the intersection of $11^{0} 8^{\prime} \mathrm{N}$ and $39^{\circ} 38^{\prime} \mathrm{E}$, which includes twenty two Woredas. The zone consists of thirty six (36) secondary schools (9-10 grade level). Among those four of them (11.12\%) were selected using purposeful sampling techniques. Regarding the sample size there are total 7,654 students ${ }^{\text {ee }}$ out of that 385 (5.03\%) sample size was taken at $95 \%$ confidence level and 5\% sampling error. To make the sample representative from four schools, stratified and random sampling method is employed. In this study, the researcher used both primary and secondary data sources.

\section{Instrument and Methods of Data Analysis}

A Likert-type scale questionnaire and Criteria-referenced test was used to elicit responses from the respondents. The data collected through different instruments were analyzed both qualitatively and quantitatively. T-test, One way ANOVA, and SPSS 19.0 were also employed.

\section{Results and Discussion}

The data from each source were organized, presented and interpreted sequentially in a way to answer the research objectives of the study:

\section{Students' Environmental Knowledge}

Environmental knowledge and understanding enables students $^{\text {ee }}$ to make informed decisions and judgments in issues, problems and actions related to the environment and its allied problems (MOE, 1994).

The criterion-referenced test consist of twenty items from both biology and geography textbooks of grade nine and ten students were prepared by the researcher. Filho (1993) suggested who acknowledge that subjects such as chemistry, biology and geography, whose subject matters are essentially environmental, are more important to address environmental and ecological issues. These host subjects present the knowledge, concern and skill that enable the learner to express and manipulate his/her environment.

Table 1: Students "e test result with respect to the Performance Standard set (70\%) correct level by their Teachers ${ }^{\mathrm{ec}}$.

\begin{tabular}{|c|c|c|c|c|c|c|c|}
\hline \multirow[t]{2}{*}{ Schools } & \multirow[t]{2}{*}{$\begin{array}{l}\text { Grade } \\
\text { level }\end{array}$} & \multicolumn{2}{|c|}{$\begin{array}{c}\text { Total } \\
\text { students } \\
\text { who took } \\
\text { the test }\end{array}$} & \multicolumn{2}{|c|}{$\begin{array}{l}\text { Students who } \\
\text { achieved } \\
\text { including above } \\
\text { the standard } \\
\end{array}$} & \multicolumn{2}{|c|}{$\begin{array}{c}\text { Students who } \\
\text { achieved } \\
\text { below the } \\
\text { standard } \\
\end{array}$} \\
\hline & & No & $\%$ & No & $\%$ & No & $\%$ \\
\hline \multirow[t]{2}{*}{ Combolcha } & 9 & 36 & 100 & 19 & 52.7 & 17 & 47.3 \\
\hline & 10 & 25 & 100 & 14 & 56 & 11 & 44 \\
\hline \multirow[t]{2}{*}{ Hote } & 9 & 76 & 100 & 19 & 25 & 57 & 75 \\
\hline & 10 & 44 & 100 & 26 & 59.1 & 18 & 40.9 \\
\hline \multirow[t]{2}{*}{ Adjibar } & 9 & 64 & 100 & 16 & 25 & 48 & 75 \\
\hline & 10 & 55 & 100 & 17 & 30.9 & 38 & 69.1 \\
\hline \multirow[t]{2}{*}{ Masha } & 9 & 55 & 100 & 19 & 34.5 & 36 & 65.5 \\
\hline & 10 & 30 & 100 & 12 & 40 & 18 & 60 \\
\hline \multirow[t]{2}{*}{ Total } & 9 & 231 & 100 & 73 & 31.6 & 158 & 68.4 \\
\hline & 10 & 154 & 100 & 69 & 44.8 & 85 & 55.2 \\
\hline
\end{tabular}

Source: Field survey, 2011

As indicated in Table 1, the majority of sampled students ${ }^{\text {ee }}$ of grade nine and ten at Adjibar (75\% and 69.1\%) and Masha (65.5\% and 60\%) respectively achieved below the standard set by their teachers ${ }^{\text {ee }}$. On the other hand, students ${ }^{\text {ee }}$ of grade nine and ten from Combolcha (52.7\% and 56\%) and Hote (59.1\%) of grade ten found to have relatively better score in the knowledge test including and above the standard. Whereas, grade nine students ${ }^{\text {ee }}$ form Hote found having low level of environment knowledge by scoring $75.1 \%$ below the standard set. Besides this, when the students ${ }^{\text {ee }}$ who achieved the standard set by their teachers" ${ }^{\text {ee }}$ are compared, grade ten students $^{\text {ee }}(44.8 \%)$ scored better than grade nine students ${ }^{\text {ee }}$ (31.6\%).

Generally, respondents from the sampled schools failed to respond more than half of the knowledge items, based on the standard set $70 \%$ correct level. This is due to lack of wider 


\section{International Journal of Science and Research (IJSR) \\ ISSN (Online): 2319-7064 \\ Index Copernicus Value (2013): 6.14 | Impact Factor (2015): 6.391}

experience and basic understanding of environmental issues. The other factor is the teaching of environmental education in the classroom has been given through infusion approach and mainly focus on chalk and talk system, which focuses on rote learning of factual knowledge about the environment. This did not equip students ${ }^{\text {ee }}$ to apply locally significant activities related to the environment what studentse already know and at the same time to expand their understanding. In addition to this, lack of students motivation and initiation while learning environmental issues in the classroom. And also lack of familiarity and exposure on how human activities affect the local environment affect their appreciation of environmental issues.

However, this might not tell us whether this difference is statistically significant. Therefore, further statistical analysis was made.

Table 2: Descriptive Statistics for Achievement Test Scores by Grade Level

\begin{tabular}{|c|c|c|c|c|}
\hline Variable & Grade & N & Mean & Standard Deviation \\
\hline $\begin{array}{c}\text { Achievement } \\
\text { test score }\end{array}$ & Nine & 231 & 60.67 & 14.42 \\
\cline { 2 - 5 } & Ten & 154 & 65.16 & 13.49 \\
\hline
\end{tabular}

Table 2 indicates that, the mean achievement score of grade nine students ${ }^{\text {ee }}$ was 60.67 with a standard deviation of 14.42 . The corresponding figures of grade ten students ${ }^{\text {ee }}$ mean achievement score were 65.16 and 13.49 respectively. This shows the existence of an observable mean difference of 4.49 between grade nine and ten students ${ }^{\text {ee }}$ for achievement mean scores. To see if these mean difference were statistically significant or not independent T-test was employed.

Table 3: T-test for Independent Sample of Grade Nine and Ten Students

\begin{tabular}{|c|c|c|c|}
\hline Variable & $\mathrm{t}$ & $\mathrm{df}$ & Mean difference \\
\hline Achievement test score & $* 3.07$ & 383 & 4.49 \\
$* \mathrm{P}<0.05$
\end{tabular}

The analysis in table 3 also showed that, there was statistically significant difference between grade nine and ten students ${ }^{\text {ee }}$ mean achievement scores, $t(383)=3.07$, $\mathrm{p}<0.05$. This showed that, grade ten students ${ }^{\text {ee }}$ were performed better than grade nine studentse (Mean difference $=4.49$ ).

The reason for significant difference in environmental knowledge between grade nine and ten students ${ }^{\text {ec }}$ might be, due to the effect of one year grade level difference, which brings the opportunities to have additionally learned knowledge and newly acquired skills or understanding of environmental issues to grade ten students.

The other factor might be there is a change in the contents of the subjects in grade ten that has the potential to bring significant difference among the studentse environmental knowledge.

On the contrary, the research finding of Budak (2005) who concluded that no significant differences were found between students ${ }^{\text {ee }}$ awareness scores when their educational level increased.

Table 4: Descriptive Statistics for Achievement Test Scores by Gender

\begin{tabular}{|c|c|c|c|c|}
\hline Variable & Gender & $\mathrm{N}$ & Mean & Standard Deviation \\
\hline $\begin{array}{c}\text { Achievement test } \\
\text { score }\end{array}$ & Male & 205 & 62.10 & 13.55 \\
\cline { 2 - 5 } & Female & 180 & 62.89 & 14.98 \\
\hline
\end{tabular}

As can be seen in Table 4, the mean achievement score of male students ${ }^{\text {ee }}$ was 62.10 with a standard deviation of 13.55 . The corresponding figures for female students ${ }^{\text {ee }}$ mean achievement score were 62.89 and 14.95 respectively. Hence, it seems that there is a slight mean difference between male and female students ${ }^{\text {ee }}$ achievement scores. To see if these mean difference were statistically significant independent T-test was employed.

Table 5: T-test Independent Sample of Male and Female Students

\begin{tabular}{|c|c|c|c|}
\hline Variable & $\mathrm{t}$ & $\mathrm{df}$ & Mean difference \\
\hline Achievement test score & $* 0.54$ & 383 & 0.79 \\
$* \mathrm{P}>0.05$
\end{tabular}

As shown in Table 5 result, there was no statistically significant difference between male and female students ${ }^{\text {ee }}$ mean achievements scores, $\mathrm{t}(383)=0.54, \mathrm{p}>0.05$.

The reason for no statistically significance difference between male and female students ${ }^{\text {ee }}$ in their environmental knowledge might be they study together in the same teaching- learning environment. The other factor may be the students"e parent give equal chance for their male and female students $^{\text {ee }}$ to attend their secondary level of education by ignoring the previous cultural taboo, this offer the opportunities to have equal competencies in their education.

Table 6: Descriptive Statistics for Mean Achievement Scores by Schools.

\begin{tabular}{|c|c|c|c|}
\hline Schools & $\mathrm{N}$ & Mean & Standard deviation \\
\hline Combolcha & 61 & 66.64 & 12.93 \\
\hline Hote & 120 & 63.71 & 15.25 \\
\hline Adjibar & 119 & 60.76 & 13.94 \\
\hline Masha & 85 & 61.17 & 13.41 \\
\hline Total & 385 & 62.47 & 14.20 \\
\hline
\end{tabular}

As can be seen in Table 6 the students ${ }^{\text {ee }}$ mean achievement score at Combolcha and Hote got the highest mean scores, 66.64 and 63.71 respectively. Whereas, the students ${ }^{\text {ee }}$ at Masha and Adjibar secondary schools got the lowest mean achievement scores, 61.17 and 60.76 respectively. To see if these mean difference among the four schools were statistically significant, One-way ANOVA was employed.

Table 7: ANOVA Summary for Achievement Test Scores by Schools

\begin{tabular}{|c|c|c|c|c|}
\hline $\begin{array}{c}\text { Source of } \\
\text { variation }\end{array}$ & $\begin{array}{c}\text { Sum of } \\
\text { squares }\end{array}$ & $\begin{array}{c}\text { Degree of } \\
\text { freedom }\end{array}$ & $\begin{array}{c}\text { Means } \\
\text { square }\end{array}$ & F-Ratio \\
\hline Between group & 1743.53 & 3 & 581.17 & $* 2.92$ \\
\cline { 1 - 4 } Within group & 75762.31 & 381 & 198.85 & \\
\hline $\mathrm{P}<0.05$
\end{tabular}

The ANOVA summary in table 7 supports that, there was statistically significant mean difference among the four 


\section{International Journal of Science and Research (IJSR) ISSN (Online): 2319-7064 \\ Index Copernicus Value (2013): 6.14 | Impact Factor (2015): 6.391}

schools, $F(3,381)=2.92, \mathrm{p}<0.05$. As observed from the mean scores, the urban background students"e of Combolcha and Hote schools, score better result than these rural background students se of Adjibar and Masha. Therefore, the difference observed in the schools might be the students "ef urban background have more information about environmental issues from informal sources such as; televisions, FM radio, magazines etc.

\section{Behavioral Practices of Students' in Their Environment}

A true Behavioral change is proven through practice which is supposed to be accomplished with the help of the acquired knowledge and the desired attitude attached to it (MOE, 1992).

This idea sounds more important in environmental education for the learning process in the area is expected to be accomplished on practical basis. Students" were asked 14 practical demanding items to express their agreement regarding the occurrence of the activities leading to the Acquisition of environmental practices. To decide the accepted and unaccepted performance, the same method used for the attitude was employed here too.

Table 8: Behavioral Practices of Grade Ten Students ${ }^{\text {ee }}$ in their Environment

\begin{tabular}{|c|c|c|c|c|c|c|c|c|}
\hline \multirow{3}{*}{ Items } & \multicolumn{7}{|c|}{ Respondents Having } \\
\cline { 2 - 9 } & \multicolumn{7}{|c|}{ Accepted performance } & \multicolumn{3}{c|}{ Unaccepted performance } \\
\cline { 2 - 9 } & 4 & 3 & total & $\%$ & 2 & 1 & Total & $\%$ \\
\hline *B1 & 28 & 69 & 97 & 62.98 & 40 & 17 & 57 & 37.01 \\
\hline B2 & 41 & 60 & 101 & 65.58 & 37 & 16 & 53 & 34.41 \\
\hline B3 & 50 & 51 & 101 & 65.58 & 38 & 15 & 53 & 34.41 \\
\hline B4 & 21 & 63 & 84 & 54.54 & 42 & 28 & 70 & 45.45 \\
\hline B5 & 20 & 47 & 67 & 43.50 & 51 & 36 & 87 & 56.49 \\
\hline B6 & 49 & 29 & 78 & 50.64 & 31 & 45 & 76 & 49.35 \\
\hline B7 & 29 & 56 & 85 & 55.19 & 45 & 24 & 69 & 44.80 \\
\hline B8 & 79 & 34 & 113 & 73.37 & 28 & 13 & 41 & 26.62 \\
\hline B9 & 69 & 41 & 110 & 71.42 & 26 & 18 & 44 & 28.57 \\
\hline B10 & 73 & 21 & 94 & 61.03 & 39 & 21 & 60 & 38.96 \\
\hline B11 & 24 & 36 & 60 & 38.96 & 41 & 53 & 94 & 61.03 \\
\hline B12 & 84 & 37 & 121 & 78.57 & 19 & 14 & 33 & 21.42 \\
\hline B13 & 54 & 36 & 90 & 58.44 & 38 & 26 & 64 & 41.55 \\
\hline B14 & 22 & 42 & 64 & 41.55 & 41 & 49 & 90 & 58.44 \\
\hline
\end{tabular}

Source: field survey, 2011

*The items are coded as numbered in the questionnaire and see appendixes.

As shown in Table 8, most of the students ${ }^{\text {ee }}$ are found having acceptable performance level regarding the occurrence of the activities leading to better environmental practices, except in items five, eleven and fourteen where, more than half of the students ${ }^{\text {ee }}$ did have unaccepted performance level in their environment. For instance, $61.03 \%$ of the students ${ }^{\text {ee }}$ did not prefer paper bags than plastic ones for shopping purpose. Whereas, only $38.96 \%$ of them agreed with this view. Moreover, $58.44 \%$ of the students ${ }^{\text {ee }}$ did not participate in schools mini-mass media to disseminate environmental issues such as; deforestation, soil erosion, global warming issues etc. And $56.49 \%$ of them did not participate in planting, trees in their school compound. Whereas, only $43.50 \%$ of them agreed with this view.
On the other hand, $73.37 \%$ of the students ${ }^{\text {ee }}$ keep papers which are printed or written on one side in order to write on the other side. Moreover, $71.42 \%$ of them keep away bottles, glasses, plastic, dead batteries and metal wastes in areas of out of the reach of children. Further, 50.64\% of the students also did turn off light in rooms which are not being used to save electricity. Whereas, $49.35 \%$ of them did not participate in such activities. Still, $61.03 \%$ of the students ${ }^{\text {ee }}$ are willing to take part in digging waste disposal pits. Whereas, only $38.96 \%$ of them did not show their willingness to take part in digging waste disposal pits.

Table 9: Behavioral Practices of Grade Nine Students ${ }^{\text {ec }}$ in Their Environment

\begin{tabular}{|c|c|c|c|c|c|c|c|c|}
\hline \multirow{2}{*}{ Items } & \multicolumn{7}{|c|}{ Respondents Having } \\
\cline { 2 - 10 } & \multicolumn{2}{|c|}{ Accepted performance } & \multicolumn{3}{c|}{ Unaccepted performance } \\
\cline { 2 - 9 } & 4 & 3 & total & $\%$ & 2 & 1 & Total & $\%$ \\
\hline *B1 & 63 & 95 & 158 & 68.39 & 48 & 25 & 73 & 31.60 \\
\hline B2 & 82 & 64 & 146 & 63.20 & 51 & 34 & 85 & 36.79 \\
\hline B3 & 84 & 72 & 156 & 67.53 & 46 & 29 & 75 & 32.46 \\
\hline B4 & 32 & 117 & 149 & 64.50 & 41 & 41 & 82 & 35.49 \\
\hline B5 & 59 & 62 & 121 & 52.38 & 58 & 52 & 110 & 47.61 \\
\hline B6 & 84 & 42 & 126 & 54.54 & 26 & 79 & 105 & 45.45 \\
\hline B7 & 59 & 82 & 141 & 61.03 & 48 & 42 & 90 & 38.96 \\
\hline B8 & 125 & 57 & 182 & 78.78 & 28 & 21 & 50 & 21.64 \\
\hline B9 & 115 & 56 & 171 & 74.02 & 36 & 24 & 60 & 25.97 \\
\hline B10 & 116 & 57 & 173 & 74.89 & 33 & 25 & 58 & 25.10 \\
\hline B11 & 41 & 51 & 92 & 39.82 & 52 & 87 & 139 & 60.17 \\
\hline B12 & 119 & 54 & 173 & 74.89 & 35 & 23 & 58 & 25.10 \\
\hline B13 & 91 & 64 & 155 & 67.09 & 43 & 33 & 76 & 32.90 \\
\hline B14 & 50 & 74 & 124 & 53.67 & 52 & 56 & 108 & 46.75 \\
\hline
\end{tabular}

Source: field survey, 2011

*The items are coded as numbered in the questionnaire and see appendix.

As computed in this way, most of grade nine students ${ }^{\text {ee }}$ were found having acceptable performance level regarding the occurrence of the activities leading, to better environmental practices like grade ten studentse ${ }^{\text {e }}$

Table 9 depicts that; students ${ }^{\text {ee }}$ did have acceptable performance level in their environment. For instance, $68.39 \%$ of the students ${ }^{\text {ee }}$ participated in and out of school practices such as planting trees in their homes. Moreover, $64.50 \%$ and $61.03 \%$ of students ${ }^{\text {ee }}$ talk with their friends about their local environmental problems and visit accessible forest areas in their surrounding respectively. On the contrary, more than half of the students ${ }^{\text {ee }}(60.17 \%)$ prefer plastic bags than paper bags for shopping purpose. Whereas, only $39.82 \%$ of them did not agree with this view. Still, $45.45 \%$ of the students ${ }^{\text {ee }}$ did not turn off light in rooms which are not being used to save electricity.

Generally, considering all of the items students ${ }^{\text {ee }}$ found to be willing to engaged in actions to help environmental protection in their surroundings. But, considering individual issues, the result is not satisfactory for some issues, as the respondents ${ }^{\text {ee }}$ were not willing to sacrifice their personal interest for the sake of environmental protection. This lack of willingness might be due to their age limitation being young may not consider that there effort is as such important for environmental quality. The other factor might be students ${ }^{\text {ee }}$ do not know that initiate their preparedness to act 


\section{International Journal of Science and Research (IJSR) \\ ISSN (Online): 2319-7064 \\ Index Copernicus Value (2013): 6.14 | Impact Factor (2015): 6.391}

friendly with the environment. They do not see efficient organizations of community groups or schools based environmental clubs which can work together to solve local environmental problems.

However, based on the analysis made using percentage of frequencies, one may not identify whether there is a statistical significant behavioral practice difference between grade nine and ten, male and female and urban and rural students $^{\text {ee }}$ in their environment. Therefore, the researcher made further statistical analysis.

Table 10: Descriptive Statistics for Environmental Practice Test Scores by Grade Level

\begin{tabular}{|c|c|c|c|c|}
\hline Variable & Grade & N & Mean & Standard deviation \\
\hline Practice test scores & Nine & 231 & 38.37 & 7.51 \\
\cline { 2 - 5 } & Ten & 154 & 38.00 & 6.82 \\
\hline
\end{tabular}

Table 10 depicts that; there was slight mean difference between the mean practice scores of grade nine and ten studentse $^{\text {ee }}$ To see if this mean difference were statistically significant, independent T-test were employed.

Table 11: T-test for Independent Sample of Grade Nine and Ten Students

\begin{tabular}{|c|c|c|c|}
\hline Variable & $\mathrm{t}$ & $\mathrm{df}$ & Mean difference \\
\hline Practice test score & $* 0.51$ & 383 & 0.37 \\
\hline
\end{tabular}

$* \mathrm{P}>0.05$

The data in table 11 also support that, there was no statistically significant difference between grade nine and ten students mean practice scores, $\mathrm{t}(383)=0.51, \mathrm{p}>0.05$. The reason for no significant difference in environmental practices between grade nine and ten students ${ }^{\text {ee }}$ might be lesser grade level difference which is only one year does not bring difference the ability to participate in solving real local environmental problems with a practical bases.

Table 12: Descriptive Statistics for Environmental Practice Test Scores by Gender.

\begin{tabular}{|c|c|c|c|c|}
\hline Variable & Gender & $\mathrm{N}$ & Mean & Standard deviation \\
\hline Practice Scores & Male & 205 & 38.19 & 7.49 \\
\cline { 2 - 5 } & Female & 180 & 38.37 & 7.18 \\
\hline
\end{tabular}

As can be seen Table 12, the mean attitude score of male students $^{\text {ec }}$ is 38.19 and with a standard deviation of 7.49. The corresponding figure of female students ${ }^{\text {ec }}$ is 38.37 and 7.18 respectively.

As shown from the mean, there is slight mean difference between the mean practice scores of male and female students ${ }^{\text {ee. }}$.

Table 13: T-test for Independent Sample of Male and Female Students ${ }^{\text {ee }}$

\begin{tabular}{|c|c|c|c|}
\hline Variable & $\mathrm{t}$ & $\mathrm{df}$ & Mean difference \\
\hline Practice test score & $* 0.26$ & 383 & 0.18 \\
\hline
\end{tabular}
$\begin{array}{rl}\mathrm{P} & 0.05\end{array}$

The findings shown in table 13 also support that, there is no statistically significant difference between male and female students $^{\text {ee }}$ mean practice scores, $\mathrm{t}(383)=0.26, \mathrm{p}>0.005$.

The reason for no significant difference in environmental practices between male and female students ${ }^{\text {ee }}$ might be they are study together in the same teaching learning environment. This enabled them to have the same level of experience for the application of their knowledge practically.

Table 14: Descriptive Statistics for Environmental Practice Mean Scores by Schools.

\begin{tabular}{|c|c|c|c|}
\hline Schools & $N$ & Mean & Standard deviation \\
\hline Combolcha & 61 & 33.64 & 6.81 \\
\hline Hote & 120 & 37.34 & 6.70 \\
\hline Adjibar & 119 & 39.35 & 6.94 \\
\hline Masha & 85 & 41.16 & 6.92 \\
\hline Total & 385 & 38.22 & 7.24 \\
\hline
\end{tabular}

As can be shown in table 14, students ${ }^{\text {ee }}$ at Masha and Adjibar got the highest mean scores is 41.16 and 39.35 respectively. Whereas, Combolcha and Hote students ${ }^{\text {ee }}$ score is 33.64 and 37.34 respectively, they got the lowest mean scores. To see if these mean difference among the four schools were statistically significant, One-way ANOVA was employed.

Table 15: ANOVA Summary for Environmental Practice Test Scores by Schools

\begin{tabular}{|c|c|c|c|c|}
\hline $\begin{array}{c}\text { Source of } \\
\text { variation }\end{array}$ & $\begin{array}{c}\text { Sum of } \\
\text { squares }\end{array}$ & $\begin{array}{c}\text { Degree of } \\
\text { freedom }\end{array}$ & $\begin{array}{c}\text { Means } \\
\text { square }\end{array}$ & \multirow{2}{*}{ F-Ratio } \\
\cline { 1 - 4 } Between group & 2309.91 & 3 & 769.972 & \multirow{2}{*}{$* 15.93$} \\
\hline Within group & 18408.44 & 381 & 48.316 & \\
\cline { 1 - 4 } Total & 20718.36 & 384 & & \\
\hline
\end{tabular}

$* \mathrm{P}<0.05$

The ANOVA summary in table 15 depicts that, there was statistically significant mean difference among the schools as a whole, $F(3,381)=15.93, p<0.05$. As observed from the mean scores, the rural background students ${ }^{\text {ee }}$ of Masha and Adjibar schools, score better result than these urban background students "e of Combolcha and Hote. Therefore, the difference observed in the schools might be the studentse of rural background have more attachments with their local environment in their day to day activities.

Good knowledge is an issue expected to result in good behavioral practice towards the same issue. The knowledge test score are performed better in Combolcha and Hote secondary school studentse than Adjibar and Masha schools. But, their behavioral practices in these schools are found in the reveres one. This implies that, having high level of knowledge and favorable environmental attitude may not necessarily bring behavioral change in an environmental friendly behavior up on the students ${ }^{\text {ee }}$.

\section{Summary and Conclusion}

The results showed that the majority of the studentse performed below the standard set $(70 \%)$ by their teachers ${ }^{\text {ec }}$ in relation to their environmental knowledge and understanding. However, when their achievement scores are analyzed in terms of the independent variables, the mean difference between grade nine and ten students ${ }^{\text {ee }}$ are found statistically significant, $\mathrm{t}(383)=3.07, \mathrm{p}<0.05$. On the other hand, the mean difference between male and female, found insignificant, $t$ (383) $=0.54, p>0.05$. And the ANOVA summary also show significant mean difference in the school as a whole, $\mathrm{F}(3,381)=2.92, \mathrm{P}<0.05$. 
Finally, regarding their behavioral practices in their environment to solve local environmental problems, students ${ }^{\text {ee }}$ are found having low practices. The analysis made based on the independent variables (grade level and gender), statistically insignificant mean difference in the students ${ }^{\text {ee }}$ behavioral practices is obtained, $\mathrm{t}$ (383) $=0.51, \mathrm{P}>0.05$ and $\mathrm{t}$ (383) $=0.26, P>0.05$ respectively. The ANOVA summary shows that, statistically significant mean difference in the schools as a whole, $\mathrm{F}(3,38)=15.93, \mathrm{P}<0.05$.

In addition to this, the teaching of environmental education in the sampled schools has been given through infusion approach and mainly focuses on chalk and talk system, which focuses on rote learning of factual knowledge about the environment. This directly affects studentse ability to integrate theory with practice. This also does not help students $^{\text {ee }}$ to develop responsibility in addressing environmental problems in their local, national and global contexts.

\section{References}

[1] Beletu Mengistu and Yosef Betremariam (1990). A Look at the Activities of the Environmental Education Project in Ethiopia. Addis Ababa.

[2] Budak, D.Budak, F. Zaimogiu, Z. Kece, S. and Yavuz, M. et-al, (2005). Behavior and attitude of students to wards environmental issues at faculty of Agriculture Turkey Journal of Applied sciences 5(7)1,224-1227, 2005www.pjoes.com/pdf/16.2/177-182.pdf

[3] EPA, (1997). Environmental policy of Ethiopia. EPA, Federal Democratic Republic of Ethiopia.

[4] Filho, W.L. and Hale, M. (1993). Promoting International Environmental education, Brazil Ministry of Education and Others.

[5] MOE. (1992). Evaluation of the Environmental Education Project in Ethiopia: final report of a joint Evaluation team (MOE, MOE and SIDA).

[6] MOE. (1994). Transitional Government of Ethiopia Education Policy. Addis Ababa, Ethiopia.

[7] Sabrina, E and Barrett. (2005). Understanding the Importance of Environmental Education; Examination of I love a clean San Diego, a local environmental nonprofit.

[8] Schneider, M. (1991). The Role of EE in Developing Countries issues for Research: Environment Management in Developing countries Paris OLED.

[9] Smith, M. 2002. Outdoor and environmental education development manager. Curriculum service http://www.hse.uk/school/trips.

[10]UN (1972). Declaration of the United Nations Conference on the Human Environment: Principle 19. http://fletcher.tufts.edu/multi/ texts/STOCKHOLMDECL.txt

[11]WWF-UK, (1988). A common purpose: Environmental education and the school. Module 2: A Whole School Approach to Environmental Education. http://www.ens.gu.edu.au/ciree/LSE/MOD2. 